\title{
Evaluation of environmental and occupational health students' attitudes toward their field of study at Ardabil University of Medical Sciences, Iran, in 2013
}

\author{
Amani F, $\mathrm{PhD}^{1}$, Daroghe F, BSc${ }^{2}$, Akharbeen K, $\mathrm{MSc}^{3}$, Ahmadi Asour A, $\mathrm{MSc}^{4 *}$ \\ 1- Assistant Prof., Dept. of Social Medicin, Faculty of Medicin, Ardabil University of Medical Sciences, Ardabil, Iran. \\ 2- Expert, Dept. of Occupational Health, Sabzevar, University of Medical Science, Sabzevar, Iran. 3- Faculty Member, Dept. \\ of Social Medicin, Faculty of Medicin, Ardabil University of Medical Sciences, Ardabil, Iran. 4- Faculty Member, Dept. of \\ Occupational Health, Sabzevar University of Medical Science, Sabzevar, Iran.
}

\begin{abstract}
Received: January 2016, Accepted: April 2016

Background: Studies show that most students do not have sufficient scientific spirit and motivation and usually do not have the right attitude toward their chosen field of study. The aim of this study was to investigate the attitudes of students in occupational and environmental health at Ardabil University of Medical Sciences, Iran, toward their disciplines.

Materials and Methods: This cross-sectional study examined the attitudes of 150 students of environmental and occupational health in relation to their field of study. The participants consisted of students who were studying at Ardabil University of Medical Sciences between 2010 and 2013. Data collection was conducted using a questionnaire. Data were analyzed using SPSS software and P values of less than 0.05 were considered as significant.

Results: The mean and standard deviation score of attitudes of occupational and environmental health students toward their field of study and their future career were $39.6 \pm 8.7$ and $44.5 \pm 8.5$ (Total: 42 ), respectively. The mean score of environmental health students was close to the acceptable limit; however, the mean score of occupational health students was less than the acceptable limit. Mean score of attitude among male students was $43.2 \pm 9.9$, while it was $41.3 \pm 8.3$ among female students, indicating that the mean score of female students was below the acceptable limit and was not significant $(\mathrm{P}=0.213)$. Mean score of attitude among single students was $42.6 \pm 8.7$, while it was $39.9 \pm 9.2$ among married students. The mean for married students was below the acceptable limit and this relationship was not significant $(\mathrm{P}=0.015)$.

Conclusions: Although the attitudes of environmental health students toward their major were positive, occupational health students' attitudes were negative. Thus, the Ministry of Health and Medical Education can accommodate students' admission to these majors considering the needs of the labor market. Moreover, these majors' curricula should be based on the real needs of society and creating new job markets should be a high priority.
\end{abstract}

Keywords: Attitude, Environmental Health, Occupational Health, Students, University, Iran.

\section{Introduction}

Attitude, a subjective variable, defines the interest or disinterest rate of individuals toward places, people, objects, items, or events. It is used to describe the pattern of feelings, opinions, and responses of an individual toward people, issues, or specific ideas and is often based on past experiences of the individual (1). Today, the study of attitude, as the most important concept of social psychology, has a special place in research.
Knowledge of attitude may be valuable in predicting and interpreting social behaviors after their occurrence. Universities are the origin of developments in society in various fields, and students as the main pillar of universities will constitute the main body of different organizations and agencies in the

\footnotetext{
* Corresponding author: Akbar Ahmadi Asour, Dept. of Occupational Health, Sabzevar University of Medical Science, Sabzevar, Iran.

Email: asour50@yahoo.com
} 
society. Thus, understanding the attitude of students toward their field of study and future career, especially in the health majors, is importance due to their vital role in public health (2).

Many studies have shown that the academic performance of students and the activities associated with it during academic training are not of high quality. Most of the students do not have sufficient scientific spirit and motivation, and instead of improving their academic level, they try to upgrade their level of education (obtain higher qualifications). There have been many reasons for this situation including the failure of universities to create and strengthen the scientific spirit, failure to choose the right major, as well as individual and personality traits. Environmental and occupational health students are no exception to this rule $(3,4)$. The educational development of students while studying at university and after graduation is highly and evidently dependent on their attitude and interests in their field of study. Therefore, various studies have assessed the interests and attitudes of medical students toward their field of study. However, given the importance of health majors, especially environmental and occupational health and the close relationship between these two disciplines, they should be investigated comprehensively. Therefore, this research was designed and conducted to evaluate environmental and occupational health students' attitudes toward their major.

In a study conducted on 1522 national university students by Serajzadeh and Javaheri, it was revealed that $15 \%$ of students were unsatisfied with their major, while $79 \%$ stated that they had insufficient motivation to pursue their study (5). Hajian and Nasiri concluded in a study that the majority of medical students have chosen their major based on interest and motivation; however, this trend changed negatively during their study (6).

The obtained results on the attitudes of nursing, midwifery, and health students of
Hamedan, Iran, showed that nearly 50\% of students were worried about their future job and $40 \%$ of health students had negative attitudes toward their future profession (7). The results obtained from medical students of Isfahan University of Medical Sciences, Iran, showed that the majority of these students had negative attitudes toward their future career and there were no significant differences between male and female subjects (8).

In a study by Rejali et al., it was reported that $95.6 \%$ of students had positive attitudes toward their field of study and the rest of the students had negative attitudes (9). In a study performed on 220 students of Arak University of Medical Sciences, Iran, it was found that $75.4 \%$ of students had a positive attitude toward their future career and $87.4 \%$ had a positive attitude toward their field of study (10). Mydhili Chellappah and Laura Garnham found that only $13 \%$ of students ranked general practice as their first choice career despite having a generally realistic and positive attitude toward the specialty. They highlighted that the main influence on future career choice was interest in the specific specialty and that lifestyle factors did not seem to be so important (11). Henderson et al. showed that medical students had a positive attitude towards general practice as a specialty and towards GPs as doctors (12). They rated personal experience of GPs as the most important factor influencing their attitude. Students' attitudes toward general practice and GPs were more positive $(\mathrm{P}<0.001)$ in the fifth year. First-year students believed the media to have a more important role in influencing their attitude than those in the fifth year $(\mathrm{P}<0.001)$ (12).

In a study performed by Lambert et al., enthusiasm for and commitment to the specialty' was a very important determinant of choice for intending doctors, regardless of their chosen specialty. Relatively few doctors had actually considered general practice seriously, but had then rejected it (13). Moreover, $78 \%$ of the doctors who rejected 
general practice presented 'job content' as their reason, compared with the $32 \%$ of doctors who rejected other specialties (13).

Therefore, the aim of this study was to compare the attitudes of environmental and occupational health students in Ardabil University of Medical Sciences, Iran, toward their chosen field of study due to the content and functional similarities between these two majors.

\section{Material and Methods}

This was a cross-sectional study in which the attitudes of environmental and occupational health students at Ardabil University of Medical Sciences were examined in relation to their field of study. The statistical population consisted of around 150 students in their first to seventh semester in 2010-2013 to evaluate the perspective of all students and factors, because students become more familiarized with the various features of study fields during their fourth year. The data collection tool was a questionnaire containing 23 questions on gender, age, educational level, field of study, and attitude measurement. The questions were scored on a 5-point Likert scale. According to the response (including strongly agree, agree, no opinion, disagree, and strongly disagree) each item could obtain a score of 1 to 5 . Content validity was used to determine the validity of the questionnaire. The reliability of the questionnaire was defined using Cronbach's alpha coefficient $(\alpha=0.727)$. On the negative attitude items, scores were calculated in reverse manner, and each student could obtain a score of 14 (minimum) to 70 (maximum) based on their attitude. Thus, data were changed numerically using ordinal scales and the total average score of all options was used as an indicator to assess attitudes. In order to determine the attitude border according to the minimum (14) and maximum (70) scores, an average of 42 was calculated. Accordingly, scores below 42 were considered as representing a negative attitude, while scores higher than 42 were taken to represent a positive attitude.

In addition, data were analyzed using t-test, ANOVA, Pearson correlation coefficient, and chi-square in SPSS software (version 19, SPSS Inc., Chicago, IL, USA) and are presented as descriptive indicators of mean, standard deviation (SD), frequency, and percentage. All $P$ values of less than 0.05 were considered as significance.

\section{Results}

In this study, 96 (64\%) students were women and the rest were men. In addition, 134 (89.3\%) students were single and $16(10.7 \%)$ were married. The field of study of 74 (49.3\%) students was environmental health and 76 (50.7\%) students were studying occupational health (Table 1). The minimum and maximum numbers were, respectively, assigned to employed and unemployed students $(3.3 \%$ and 96.7\%). Among the students, 13 (8.7\%) had low income, 95 (63.3\%) had medium income, and 42 (28\%) had good income (Table 1). First, third, fourth, fifth, sixth, and seventh semester students constituted 40 (26.7\%), 43 (28.7\%), 2 (1.3\%), 37 (24.7\%), $15(10 \%)$, and $13(8.6 \%)$ of the total number of students, respectively. The mean and standard deviation scores of attitudes of occupational health and environment health students toward their field of study and their future career were $39.6 \pm 8.7$ and $44.5 \pm 8.5$ (Total: 42 ), respectively.

The attitude score of environmental health students was close to the acceptable limit, while it was lower than the acceptable limit in occupational health students. Mean attitude score among male and female students was $43.2 \pm 9.9$ and $41.3 \pm 8.3$, respectively, indicating that the results of male students were close to the acceptable limit. However, the score of female students was below the acceptable limit and this relationship was not significant $(P=0.213)$.

Mean attitude score among single and married students was $42.6 \pm 8.7$ and $39.9 \pm 9.2$, respectively. The mean score of single 
students was close to the acceptable limit, whereas, it was below the acceptable limit for married students and this relationship was not significant $(P=0.015)$. The mean score of employed students was $34.2 \pm 11.3$, which was below the acceptable limit. However, the mean score obtained for unemployed students was $42.3 \pm 8.8$, which was close to the acceptable limit and this relationship was significant $(\mathrm{P}=$ 0.046). The minimum and maximum attitude scores of students were 23 and 66, respectively (Table 2).

Table 1: Demographic data on environmental health and occupational health students

\begin{tabular}{|c|c|c|c|c|c|}
\hline \multirow{2}{*}{\multicolumn{2}{|c|}{ Variables }} & \multicolumn{2}{|c|}{ Environmental health } & \multicolumn{2}{|c|}{ Occupational health } \\
\hline & & $\mathbf{N}$ & $(\%)$ & $\mathbf{N}$ & $(\%)$ \\
\hline \multirow{3}{*}{ Accommodation } & Dormitory & 35 & 47 & 53 & 69.7 \\
\hline & Home & 39 & 53 & 21 & 27.7 \\
\hline & Tenant & 0 & 0 & 2 & 2.6 \\
\hline \multirow{2}{*}{ Marital status } & Single & 70 & 94.6 & 70 & 84.2 \\
\hline & Married & 4 & 5.4 & 4 & 15.8 \\
\hline \multirow{2}{*}{$\begin{array}{c}\text { Employment } \\
\text { status }\end{array}$} & Employed & 2 & 2.7 & 3 & 4 \\
\hline & Unemployed & 72 & 97.3 & 73 & 96 \\
\hline \multirow{3}{*}{ Economic status } & Weak & 5 & 6.7 & 8 & 10.5 \\
\hline & Average & 50 & 67.6 & 45 & 59.2 \\
\hline & Good & 19 & 25.7 & 23 & 30.3 \\
\hline \multirow{4}{*}{ Entrance year } & 2010 & 13 & 17.4 & 15 & 19.7 \\
\hline & 2011 & 22 & 33 & 17 & 22.3 \\
\hline & 2012 & 19 & 25.6 & 24 & 31.6 \\
\hline & 2013 & 20 & 27 & 20 & 16.4 \\
\hline \multirow{7}{*}{ Term } & 1 & 20 & 27 & 20 & 26.4 \\
\hline & 2 & 0 & 0 & 0 & 0 \\
\hline & 3 & 19 & 25.6 & 24 & 31.5 \\
\hline & 4 & 2 & 2.7 & 0 & 0 \\
\hline & 5 & 20 & 27 & 17 & 22.4 \\
\hline & 6 & 0 & 0 & 15 & 19.7 \\
\hline & 7 & 13 & 17.7 & 0 & 0 \\
\hline
\end{tabular}

In this study, Pearson correlation coefficient results illustrated an inverse and weak correlation between students' age and their attitudes toward their field of study and this correlation was not significant $(\mathrm{r}=-0.01)(\mathrm{P}=$ $0.865)$. The score of attitude toward future career decreases with age. The relationship between gender and students' attitudes toward their field of study was analyzed using the ttest and was found to be not significant $(\mathrm{P}=$ 0.213). The connection between the students' major and attitude toward their field of study was evaluated using the t-test and was found to be significant. That is, environment health students had positive attitudes toward their field of study; however, occupational health students had negative attitudes toward their field of study $(\mathrm{P}=0.001)$. The relationship between students' accommodation and their attitudes toward their field of study were analyzed using ANOVA; it was not significant $(\mathrm{P}=0.366)$. The relationship between students' economic status and their attitude toward their field of study, which was analyzed using ANOVA, was not significant $(\mathrm{P}=0.876)$. The relationship between students' years of entry and their attitudes toward their major, which was investigated using ANOVA, was not significant $(\mathrm{P}=$ 0.188). The relationship between the number of semesters attended by students and their attitudes toward their major was assessed using Spearman's correlation coefficient. This 
weak and inverse correlation was not significant $(\mathrm{r}=-0.015)(\mathrm{P}=0.860)$.

Table 2: Absolute and relative frequency distribution of students' responses to attitude questions

\begin{tabular}{|c|c|c|c|c|c|c|c|c|c|c|}
\hline & \multicolumn{2}{|c|}{$\begin{array}{l}\text { Strongly agree } \\
\mathrm{N}(\%)\end{array}$} & \multicolumn{2}{|c|}{$\begin{array}{l}\text { Agree } \\
\mathrm{N}(\%)\end{array}$} & \multicolumn{2}{|c|}{$\begin{array}{l}\text { Neutral } \\
\mathrm{N}(\%)\end{array}$} & \multicolumn{2}{|c|}{$\begin{array}{l}\text { Disagree } \\
\mathrm{N}(\%)\end{array}$} & \multicolumn{2}{|c|}{$\begin{array}{l}\text { Strongly is } \\
\text { agree } \\
\mathrm{N}(\%)\end{array}$} \\
\hline & $\begin{array}{c}\text { Environ } \\
\text { mental }\end{array}$ & $\begin{array}{l}\text { Occup } \\
\text { ational }\end{array}$ & $\begin{array}{c}\text { Environ } \\
\text { mental }\end{array}$ & $\begin{array}{l}\text { Occup } \\
\text { ational }\end{array}$ & $\begin{array}{l}\text { Environ } \\
\text { emental }\end{array}$ & $\begin{array}{l}\text { Occup } \\
\text { ational }\end{array}$ & $\begin{array}{c}\text { Environ } \\
\text { mental }\end{array}$ & $\begin{array}{l}\text { Occup } \\
\text { ational }\end{array}$ & $\begin{array}{c}\text { Environ } \\
\text { mental }\end{array}$ & $\begin{array}{l}\text { Occup } \\
\text { ational }\end{array}$ \\
\hline $\begin{array}{l}\text { I picked this major because with } \\
\text { my grades, I could only get } \\
\text { accepted in this major. }\end{array}$ & $\begin{array}{c}27 \\
(36.5)\end{array}$ & $\begin{array}{c}25 \\
(32.9)\end{array}$ & $\begin{array}{c}26 \\
(35.1)\end{array}$ & $\begin{array}{c}25 \\
(32.9)\end{array}$ & $3(4.1)$ & $\begin{array}{c}5 \\
(6.6)\end{array}$ & $\begin{array}{c}13 \\
(17.6)\end{array}$ & $\begin{array}{c}15 \\
(19.7)\end{array}$ & $5(6.8)$ & $\begin{array}{c}6 \\
(7.9)\end{array}$ \\
\hline $\begin{array}{l}\text { I am happy to have chosen this } \\
\text { major. Course objectives are } \\
\text { compatible with individual needs } \\
\text { and students' expectations. }\end{array}$ & $\begin{array}{c}16 \\
(21.6)\end{array}$ & $\begin{array}{c}9 \\
(11.8)\end{array}$ & $\begin{array}{c}25 \\
(33.8)\end{array}$ & $\begin{array}{c}16 \\
(21.1)\end{array}$ & $\begin{array}{c}8 \\
(10.8)\end{array}$ & $\begin{array}{c}10 \\
(13.2)\end{array}$ & $\begin{array}{c}15 \\
(20.3)\end{array}$ & $\begin{array}{c}34 \\
(44.7)\end{array}$ & $\begin{array}{c}10 \\
(13.5)\end{array}$ & $\begin{array}{c}7 \\
(9.2)\end{array}$ \\
\hline $\begin{array}{l}\text { After studying in this major, I } \\
\text { became more interested in it. }\end{array}$ & $\begin{array}{c}14 \\
(18.9)\end{array}$ & $\begin{array}{c}6 \\
(7.9) \\
\end{array}$ & $\begin{array}{c}21 \\
(28.4)\end{array}$ & $\begin{array}{c}15 \\
(19.7)\end{array}$ & $\begin{array}{c}13 \\
(17.6)\end{array}$ & $\begin{array}{c}6 \\
(7.9) \\
\end{array}$ & $\begin{array}{c}18 \\
(24.3) \\
\end{array}$ & $\begin{array}{c}40 \\
(52.6) \\
\end{array}$ & $8(10.8)$ & $\begin{array}{c}9 \\
(11.8)\end{array}$ \\
\hline $\begin{array}{c}\text { I believe this major becomes } \\
\text { more valuable in higher } \\
\text { education. }\end{array}$ & $6(8.1)$ & $\begin{array}{c}7 \\
(9.2)\end{array}$ & $6(8.1)$ & $\begin{array}{c}10 \\
(13.2)\end{array}$ & $17(23)$ & $\begin{array}{c}6 \\
(7.9)\end{array}$ & $\begin{array}{c}24 \\
(32.4)\end{array}$ & $\begin{array}{c}33 \\
(43.4)\end{array}$ & $\begin{array}{c}21 \\
(28.4)\end{array}$ & $\begin{array}{c}20 \\
(26.3)\end{array}$ \\
\hline $\begin{array}{c}\text { I think students of other majors } \\
\text { have a positive attitude toward } \\
\text { my major. }\end{array}$ & $\begin{array}{c}25 \\
(33.8)\end{array}$ & $\begin{array}{c}11 \\
(14.5)\end{array}$ & $\begin{array}{c}28 \\
(37.8)\end{array}$ & $\begin{array}{c}25 \\
(32.9)\end{array}$ & $2(2.7)$ & $\begin{array}{c}13 \\
(17.1)\end{array}$ & $\begin{array}{c}11 \\
(14.9)\end{array}$ & $\begin{array}{c}20 \\
(26.3)\end{array}$ & $8(10.8)$ & $\begin{array}{c}7 \\
(9.2)\end{array}$ \\
\hline $\begin{array}{c}\text { After my bachelor's degree, I } \\
\text { will continue my studies to } \\
\text { higher levels. }\end{array}$ & $\begin{array}{c}19 \\
(25.7)\end{array}$ & $\begin{array}{c}8 \\
(10.5)\end{array}$ & $\begin{array}{c}28 \\
(37.8)\end{array}$ & $\begin{array}{c}24 \\
(31.6)\end{array}$ & $7(9.5)$ & $\begin{array}{c}12 \\
(15.8)\end{array}$ & $\begin{array}{c}16 \\
(21.6)\end{array}$ & $\begin{array}{c}25 \\
(32.9)\end{array}$ & $4(5.4)$ & $\begin{array}{c}7 \\
(9.2)\end{array}$ \\
\hline $\begin{array}{l}\text { Courses offered are applicable to } \\
\text { the workplace. }\end{array}$ & $\begin{array}{c}10 \\
(13.5)\end{array}$ & $\begin{array}{c}6 \\
(7.9)\end{array}$ & $\begin{array}{c}21 \\
(28.4)\end{array}$ & $\begin{array}{c}11 \\
(14.5)\end{array}$ & $20(27)$ & $\begin{array}{c}10 \\
(13.2)\end{array}$ & $\begin{array}{c}19 \\
(25.7)\end{array}$ & $\begin{array}{c}38 \\
(50)\end{array}$ & $4(5.4)$ & $\begin{array}{c}11 \\
(14.5)\end{array}$ \\
\hline $\begin{array}{c}\text { I think the society I live in has a } \\
\text { positive attitude toward my } \\
\text { major. }\end{array}$ & $\begin{array}{c}22 \\
(29.7)\end{array}$ & $\begin{array}{c}10 \\
(13.2)\end{array}$ & $\begin{array}{c}30 \\
(40.5)\end{array}$ & $\begin{array}{c}22 \\
(28.9)\end{array}$ & $\begin{array}{c}8 \\
(10.8)\end{array}$ & $\begin{array}{c}13 \\
(17.1)\end{array}$ & $8(10.8)$ & $\begin{array}{c}16 \\
(21.1)\end{array}$ & $6(8.1)$ & $\begin{array}{c}15 \\
(19.7)\end{array}$ \\
\hline $\begin{array}{c}\text { Professors in this major } \\
\text { encourage students to look for } \\
\text { good jobs. }\end{array}$ & $\begin{array}{c}23 \\
(31.3)\end{array}$ & $\begin{array}{c}22 \\
(28.9)\end{array}$ & $\begin{array}{c}16 \\
(21.6)\end{array}$ & $\begin{array}{c}23 \\
(30.3)\end{array}$ & $\begin{array}{c}16 \\
(21.6)\end{array}$ & $\begin{array}{c}15 \\
(19.7)\end{array}$ & $\begin{array}{c}11 \\
(14.9)\end{array}$ & $\begin{array}{c}12 \\
(15.8)\end{array}$ & $8(10.8)$ & $\begin{array}{c}4 \\
(5.3)\end{array}$ \\
\hline $\begin{array}{l}\text { In my opinion, the benefits of } \\
\text { legal employment in this field } \\
\text { are great. }\end{array}$ & $6(8.1)$ & $\begin{array}{c}6 \\
(7.9)\end{array}$ & $\begin{array}{c}10 \\
(13.5)\end{array}$ & $\begin{array}{c}13 \\
(17.1)\end{array}$ & $17(23)$ & $\begin{array}{c}5 \\
(6.6)\end{array}$ & $\begin{array}{c}30 \\
(40.5)\end{array}$ & $\begin{array}{c}36 \\
(47.4)\end{array}$ & $\begin{array}{c}11 \\
(14.9)\end{array}$ & $\begin{array}{c}16 \\
(21.1)\end{array}$ \\
\hline $\begin{array}{l}\text { I do not worry about the job } \\
\text { market in this field. }\end{array}$ & $\begin{array}{c}14 \\
(18.9)\end{array}$ & $\begin{array}{c}9 \\
(11.8) \\
\end{array}$ & $3(4.1)$ & $\begin{array}{c}6 \\
(7.9)\end{array}$ & $5(6.8)$ & $\begin{array}{c}10 \\
(13.2)\end{array}$ & $20(27)$ & $\begin{array}{c}32 \\
(42.1) \\
\end{array}$ & $\begin{array}{c}32 \\
(43.2) \\
\end{array}$ & $\begin{array}{c}19 \\
(25)\end{array}$ \\
\hline $\begin{array}{l}\text { I think the employment situation } \\
\text { is better for lower degrees than } \\
\text { higher degrees in this field. }\end{array}$ & $\begin{array}{c}10 \\
(13.5)\end{array}$ & $\begin{array}{c}7 \\
(9.2)\end{array}$ & $17(23)$ & $\begin{array}{c}11 \\
(14.5)\end{array}$ & $\begin{array}{c}12 \\
(16.2)\end{array}$ & $\begin{array}{c}12 \\
(15.8)\end{array}$ & $20(27)$ & $\begin{array}{c}23 \\
(30.3)\end{array}$ & $\begin{array}{c}15 \\
(20.3)\end{array}$ & $\begin{array}{c}23 \\
(30.3)\end{array}$ \\
\hline $\begin{array}{l}\text { I like working in this field of } \\
\text { study. }\end{array}$ & $\begin{array}{c}15 \\
(20.3)\end{array}$ & $\begin{array}{c}8 \\
(10.5)\end{array}$ & $\begin{array}{c}18 \\
(24.3)\end{array}$ & $\begin{array}{c}20 \\
(26.3)\end{array}$ & $\begin{array}{c}12 \\
(16.2)\end{array}$ & $\begin{array}{c}10 \\
(13.2)\end{array}$ & $20(27)$ & $\begin{array}{c}36 \\
(47.4)\end{array}$ & $9(12.2)$ & $\begin{array}{c}2 \\
(2.6)\end{array}$ \\
\hline
\end{tabular}

\section{Discussion}

In this study, the mean score of occupational health students' attitudes towards their academic major was lower than the acceptable limit. Nevertheless, environment health students' mean attitude score was close to the acceptable limit. Results of a study conducted in Qazvin University of Medical Sciences, Iran (14) showed that the scores of environment 
health students' attitudes toward their major and future career were lower than the acceptable level. However, occupational health students' attitude scores were acceptable. Furthermore, male environment health students' attitudes were positive, but female students' scores were lower than the acceptable level. Among both male and female students in the field of occupational health, attitude toward the field of study and future career was at an acceptable level (14). Henderson et al. found that medical Students' attitudes toward general practice and GPs were more positive $(\mathrm{P}<0.001)$ in the fifth year. The results of this study showed that $58 \%$ of students have a negative attitude toward their discipline and the rest have a positive attitude (12). However, the results of a survey conducted in Arak showed that $87.4 \%$ of students had a positive attitude toward their field of study (10). In addition, career and academic attitude scores among students studying toward an associate, undergraduate, and graduate degree in environmental health in Hamedan University of Medical Sciences, Hamedan, were lower than the acceptable level (15).

According to the results of this study, 3.3\% and $96.7 \%$ of students were employed and unemployed, respectively. The reasons for the increase in the unemployed population can be the considerably higher number of students trained in this field compared to the requirement and the masculine nature of the field of activity for the graduates of these majors despite the high acceptance of female students in these fields of study. The results regarding the employment status of environmental health graduates during the years 1996-2003 showed that $64.6 \%$ of associate degree, $42.7 \%$ of bachelor's degree, and $3.7 \%$ of master's degree graduates were unemployed. Furthermore, the majority of the unemployed were female gradates (16).

The results of the current study show that $44.6 \%$ of environmental health students and $36.8 \%$ of occupational health students declared that the courses taught are not practical and useful in the workplace. The results of a study at the Qazvin University of Medical Sciences showed that $45.3 \%$ of environmental health students and $35.9 \%$ of occupational health students stated that courses and their content taught in these two fields of study do not meet the career needs of graduates in the workplace (8). These findings are consistent with the results of the present study, indicating that $71.6 \%$ of environmental health students and $65.8 \%$ of occupational health students mentioned that they were forced to choose these majors because of their rank in the entrance examination. This result confirms the results obtained for occupational health students as their attitude toward their major was negative. However, in a study performed on the attitudes of medical students at Babol University of Medical Sciences, Iran, it was shown that although the majority of students (74\%) had chosen this field of study, but $60 \%$ of students' attitudes toward their chosen field had changed (6). That is, the majority of them had negative attitudes (6).

In a study conducted in Pennsylvania School of Medicine, it was found that $90 \%$ of medical students were satisfied with their educational program and were optimistic toward their future career (17), which is not in accordance with the results of the current study. This study showed that the attitudes of environmental health and occupational health students toward their major were positive and negative, respectively. However, in the study by Mydhili Chellappah et al., the main influence on future career choice was interest in the specific specialty. In fact, considering attitudes toward the field of study, the results of this research are consistent with that of the present study, as the scores of environmental health major are higher than that of occupational health major. These results were analyzed using chi-square test and the difference was significant $(\mathrm{P}=$ 0.003). The study showed that $55.4 \%$ of environmental health students and $32.9 \%$ of occupational health students stated that they 
were satisfied with their selected major, and $58.1 \%$ of environment health students and $36.9 \%$ of occupational health students stated that their professors encouraged the students to find a suitable job. Regarding attitudes' toward the field of study, the results of these two studies are consistent. The attitude scores of environmental health major are higher than occupational health major; the results were analyzed using chi-square test and this difference was significant $(\mathrm{P}=0.017)$.

Increase in admission of students without regarding the needs of the labor market and merely to respond to the increasing need for applicants to universities in recent years, and lack of necessary infrastructure development creates a mood of despair in students regarding their future career.

\section{Conclusion}

Although the attitudes of environmental health students toward their major were positive, occupational health students' attitudes were negative. Both environmental health and occupational health students' attitudes toward their discipline were not satisfactory. Thus, the Ministry of Health and Medical Education can accommodate students' admission to these majors considering the needs of the labor market. Moreover, these majors' curricula should be based on the real needs of society and creating new job markets should be a high priority. Exam candidates should be fully aware of all disciplines in order to improve their selection of fields of study. In addition, professors should make efforts to motivate students as they are considered the most influential individuals with regard to the attitudes of students.

\section{Acknowledgement}

The authors sincerely thank the representative who helped in carrying out this research.

Conflict of interests: None declared.

\section{References}

1. Ziaeeha M, Mohammadi zeidi I, Pakpour haji agha A. Attitude of health and paramedical students towards patients with intellectual disability and severe mental health problems. The Journal of Medical Education and Development 2012; 5(2):3-9.

2. Sharifi M R, Taheri Nassaj H. Medical students' attitude towards studying medicine. Iranian Journal of Medical Education 2001; 1(4):36-43.

3. Hamdi MR, Soleimani B, Nasr Isfahani B, Mandegar HA. Evaluation of graduate student from 1989 to 1994 in school of health regarding their employment or continuing education. Journal of Research in Medical Sciences 1998; 3(1):32-6.

4. Saeedi Rezvani M, Hosseinzadah M, Baghgoli $\mathrm{H}$. The occupational destiny of education and psychology students graduated from Ferdowsi University of Mashhad. Studies in Education and Psychology 2011; 11(2):57-85.

5. Javahery F, Serajzadah SH. Attitude and behavior students public universities. Tehran: Cultural Studies and Social Planning and Research Ministry of Sciences and Technology; 2004.

6. Hajian K, Mahmoudi Pour A. Evaluation of medical student's attitude toward future job in Babol University of Medical Sciences. Journal of Medical University of Babol 2003; 8(1):8695.

7. Satari J, Jamalian S, Seifoleslami A. The study of nursing, midwifery and health students in Hamedan University of Medical Sciences towards their future career. Scientific Journal of Hamadan University of Medical Sciences and Health Services 2001; (7)4:15-9.

8. Sadr Arhami N, Kalantari S, Atarod S. Medical students attitude towards their field of study and future career. Iranian Journal of Medical Education 2004; 4(1):76-81.

9. Rejali M, Mostajeran M, Lotfi M. Isfahan medical science university, school of health students' attitudes toward the health science field and his career in 2009. Journal of Health System Research 2011; 5(1):106-15.

10. Mobarakabadi A, Shamsi M, Najafianzadeh M. Health student attitude towards their field of study and future career in health faculty of Arak University of Medical Sciences, Iran. Journal of Strides in Development of Medical Education 2014; 11(2):280-5.

11. Chellappah M, Garnham L. Medical students' attitudes towards general practice and factors affecting career choice: a questionnaire study. London J Prim Care (Abingdon) 2014; 6(6):117-23. 
12. Henderson E, Berlin A, Fuller J. (2002) Attitude of medical students towards general practice and general practitioners. Br J Gen Pract 2002; 52(478):359-63.

13. Lambert T, Goldacre R, Smith F, Goldacre MJ. Reasons why doctors choose or reject careers in general practice: national surveys. Br J Gen Pract 2012; 62(605):e851-8.

14. Jamali H A, Ghalenoei M. Attitudes of environmental health and occupational health students toward their discipline and future career in Qazvin University of Medical Sciences in 2012. Iranian Journal of Medical Education 2013; 13(7):541-50

15. Samadi M T, Taghizadeh J, Kashitarash
Esfahani Z, Mohammadi M. Evaluating environmental health students' attitudes toward their discipline and future career in Hamedan University of Medical Sciences in 2008. Iranian Journal of Medical Education 2010; 9(4):331-6.

16. Malakoutian M, Parvaresh A. The employment situation of environmental health graduates in Iran between 1996- 2002. Iranian Journal of Medical Education 2003; 3(2):65-71.

17. Watt CD, Greeley SA, Shea JA, Ahn J. Educational views and attitudes and career goals of MD-PhD students at University of Pennsylvania School of medicine. Acad Med 2005; 80(2):193-8. 